\title{
Perceived Health Impacts of Teenage Pregnancy among Married Adolescents in Peri-urban Areas of Kathmandu Valley
}

Ishwor Prasad Neupane*

\begin{abstract}
Teenage pregnancy is an issue that calls for more education and support to encourage girls to delay motherhood until they are ready. The developing countries have a large proportion of young people in the world and teenage pregnancy has emerged as one of the major public health problems. The objective of this research paper is to identify the health problems, and social consequences associated with teenage pregnancy with particular reference of peri-urban dwellers in the Kathmandu Valley. A rural health centre based cross sectional study was done with 15-19 years old 300 teenage pregnant girls as subject of the research. Peri-urban areas were purposively selected from Lalitpur District and the samples were selected from the health care centre records. The sampled units were interviewed by using standardized semi-structured questionnaire at their place of residents.
\end{abstract}

Keywords: consequences, age at marriage, adolescents, reproductive health, substance abuse.

\section{Introduction}

Teenage pregnancy is a public health concern both in developed and developing countries (Lawlor and Shaw, 2004; Jonhson and et al., 2001; Chedraui and et al., 2004). About 19 per cent of young women in developing countries become pregnant before age 18. About 95 per cent of the world's births to adolescents occur in developing countries. Every year in developing countries, 7.3 million girls under the age of 18 give birth. When a girl becomes pregnant or has a child, her health, education, earning potential and her entire future may be in jeopardy, trapping her in a lifetime of poverty, exclusion and powerlessness (UNFPA, 2013). According to the global report an estimated 16 million girls between 15 - 19 years old give birth each year, 90 percent of adolescent births among 15-19 year olds occur within marriage and in the poorest regions of the world, birth rates for 15-19 year olds is still four times higher than in the high-income regions (UNFPA, 2017). Thus, the problems are prominent in the developing countries. The risk of death due to pregnancy-related causes is double among women aged 15-19 compared to women in their twenties (PRB, 2002). Young women are also at risk of unwanted pregnancies, sexually transmitted infections and unsatisfactory or coerced early sexual relationships (Sing, 2000 and Wight et al., 2000) and these issues are have significant effects on health promotion in the developing countries in the world. Health promotion is the process of enabling people to increase, control over and to improve their health. It moves beyond a focus on individual behaviour towards a wide range of social and environmental interventions (WHO 2017).

In the developing countries, one-third to onehalf of women become mothers before the age of 20 and pregnancy related complications have become the leading causes of death among them (UN, 1997; Viegas et al., 1992). South Asian countries like India, Pakistan, Sri Lanka, Nepal, Maldives, Bhutan and Bangladesh have high proportions of teenage pregnancies, since early marriage is common and there is a social expectation to have a child soon after marriage (Stone et al., 2003; Mathor et al., 2004 and Adhikari et al., 2004). A study showed that nearly 60 percent of all girls are married by the age of 18 years and one fourth is married by the age of 15 years in South Asian countries (Mehra et al., 2004). In most areas

* Associate Professor, Sanothimi Campus, Bhaktapur 
women who attain more formal education are more likely to delay childbearing, as well as marriage, than their peers with little or no schooling (Barker, 1992). Teenage marriages are predominant in developing world including Nepal. Study shows that the median age at first marriage among women and men has increased by 1 year over the past decade. On average, women marry 4 years earlier than men (17.9 years versus 21.7 years) (NDHS, 2016).

Among the various health concerns, adolescent fertility is major one. They are more likely to suffer from severe complications of pregnancy and children (NDHS, 2001). Report shows that among women age 15-19, 17\% have begun childbearing, the same proportion reported in 2011. Thirteen percent have had a live birth, and 4 percent are pregnant with their first child (NDHS, 2016). There are some extrinsic factors such as inadequate prenatal care, illiteracy and poor socio economic condition that affect the outcome of pregnancy in teenage girls. This article examines the perceived health impacts of teenage pregnancy among married adolescents girls living in peri-urban areas of Kathmandu valley.

\section{Methods}

This article is based on primary data which were collected in August, 2017. Primary data were collected by using standardized semistructured questionnaire whereas secondary information was collected from published and unpublished literature. To collect primary information, a list was prepared through the health centre records of teenage pregnant girls of age between 15-19 years. All such 300 teenage pregnant girls were selected for interviews. Interviews were conducted in privacy without presence of family members to extract correct information on sexuality, pregnancy and its socio-cultural and other aspects through a trial-tested semi-structured questionnaire. Female trained interviewers were mobilised to get insight of the issues to be discussed in the interview. The collected data then organised and systematically entered into SPSS software to draw precise tables.

\section{Result and Discussion}

The total 300 respondents (subjects) were selected from Lubhu, Lamatar and Godamchaur VDCs of Lalitpur district within the Kathmandu Valley. Those VDCs were purposively selected as peri-urban areas of the district. All respondents (subjects) were between 15-19 years old pregnant girls. The marital status of the teenage pregnancy in 90.67 per cent cases is found to be married whereas in 4 (2.67 per cent) was found to be living together with delay marriage (Table -1). Similarly, 1.33 per cent, 2.67 per cent and 0.67 per cent of teenage pregnant girls were found divorced, separated and widowed respectively. On the other hand Demographic Health survey of 2016 had shown that out of total 15-19 years women, 72.5 percent were never married, 27.1 percent were married and in union, 0.1 percent were divorced, 0.2 were separated and no widow women were found. 
Table 1. Percentage Distributions of Teenage Pregnancy Related Matters

\begin{tabular}{|c|c|c|c|}
\hline Outcomes or variables & Status/variables & No. & Percent \\
\hline \multirow{6}{*}{$\begin{array}{l}\text { Marital status among teenage } \\
\text { pregnancy }\end{array}$} & Married & 272 & 90.67 \\
\hline & Living together & 14 & 4.67 \\
\hline & Separated & 8 & 2.67 \\
\hline & Divorce & 4 & 1.33 \\
\hline & Widow & 2 & 0.67 \\
\hline & Total & 300 & 100.00 \\
\hline \multirow{5}{*}{$\begin{array}{l}\text { Substance abuse status among } \\
\text { teenage pregnancy }\end{array}$} & No addiction & 164 & 54.67 \\
\hline & Cigarette & 90 & 30.00 \\
\hline & Alcohol & 24 & 8.00 \\
\hline & Both & 22 & 7.33 \\
\hline & Total & 300 & 100.00 \\
\hline \multirow{9}{*}{$\begin{array}{l}\text { Perceived impacts of early } \\
\text { pregnancy }\end{array}$} & School dropout & 56 & 28.87 \\
\hline & Bearing the health risk & 46 & 23.71 \\
\hline & Handicapped in getting job & 38 & 19.59 \\
\hline & Polygamy marriages & 26 & 13.40 \\
\hline & Infertility & 12 & 6.19 \\
\hline & Separations & 10 & 5.15 \\
\hline & Divorce & 4 & 2.06 \\
\hline & Widowed & 2 & 1.03 \\
\hline & Total & 194 & 100.00 \\
\hline \multirow{4}{*}{$\begin{array}{l}\text { Perceived complications of teenage } \\
\text { pregnancy on health promotion }\end{array}$} & Frequent bleeding & 172 & 57.33 \\
\hline & Abortion & 92 & 30.67 \\
\hline & Preterm delivery & 36 & 12.00 \\
\hline & Total & 300 & 100.00 \\
\hline \multirow{5}{*}{$\begin{array}{l}\text { Number of pregnancy amongst the } \\
\text { teenage girls }\end{array}$} & One pregnancy & 144 & 48.00 \\
\hline & Two pregnancy & 136 & 45.33 \\
\hline & Three pregnancy & 16 & 5.33 \\
\hline & Four and more & 4 & 1.33 \\
\hline & Total & 300 & 100.00 \\
\hline
\end{tabular}

The data (Table 1) also reveal that more than 90 percent teenage girls were married with their consent, forcefully or due to various, socio-economic factors. Moreover, with divorce (1.33 percent), separation (2.67 per cent), living together without marriage (4.67 per cent) and widow ( 0.67 per cent) indicate the ill health of the society revealing unsafe health consequences with teenage pregnancy due to the cause of early marriage.

Substances abuse was observed in teenage but exact percentage could not be determined as 164 (54.67 per cent) were not involved in substances abuse. However, cigarette use is commonly found in $90(30.0 \%)$, alcohol in 8 per cent and both (alcohol and cigarette) in 7.33 per cent (Table -1$)$.

If we look at the social impact (Table-1 ) 56 (28.87 per cent) had school dropout problem, followed by bearing the health risk $(23.71 \%)$, handicapped in getting job (19.59\%) along with least in widowed $(1.03 \%)$. State of world population 2013, world widely had shown that when a girl becomes pregnant or has a child, her health, education, earning potential and her entire future may be in jeopardy, trapping her in a lifetime of poverty, exclusion and powerlessness. There were more or less 
similarities in social as well as health related impact. There may be more complication in rural and Nepal like developing countries as the study indicated.

Similarly, if we look at the complications of teenage pregnancy, frequent bleeding in 172 (57.33 per cent) indicates as most prevalent among the respondents which may cause anemic problem. The complication of preterm delivery was found in 36 (12 per cent) and abortion in 92 (30.67 per cent) was found with early marriage problems (Table-1). WHO report shows $36-40$ per cent is anemic in the developing countries due to iron deficiency and it is common complication of teenage pregnancy (WHO 2005). Anemic status of the pregnancy within the respondent indicates the serious health and social problems though it is found common phenomena in the study area.

Looking at the frequency of pregnancy amongst the studied respondents, it was observed that 144 (48 per cent) with first pregnancy, 136 (45.33 per cent) with second pregnancy, 16 (5.33 per cent) with third pregnancy and 4 (1.33 per cent) with forth pregnancy or more than four (Table:1). This means more than 50 percent respondents were found having with more than one pregnancy. The figure also indicates the risk factors associated with health and teenage pregnancy. NDHS shows that among teenage of 15-19 years, 30.2 percent had live birth and 5.2 percent were pregnant with first child at the age of 19 while at the age of 18, 22.4 percent of teenage had live birth and 5.8 per cent were pregnant with first child. This percentage was found in ascending order as age reduces. This also shows the vulnerable situation of teenage pregnancy.

\section{Conclusion}

Marriage at adolescence and conception at these age is often referred to as 'at risk pregnancy' and cause of great concern. The risk is very much high for poor socio economic, anemic, literates a poor utilization of health services. The problems increase if they fall victims of traditional healer care taker in rural areas. The problem of teenaged motherhood is linked with child survival, maternal mortality.

The age of marriage is different region to region and in rural area as of Nepal due to traditional beliefs (Adhikari, 2003). Like family needs to reduce expenditure and to take care of other sibling while parents are at work in field. Most of rural adolescent are unaware of family planning methods.

This study shows that illiteracy, poverty, lack of sexuality education (family life education) were more prevalent factors especially in periurban area among teenagers. This requires the need for enhancing family life education to delay age at first pregnancy. This can prevent complications in teenage pregnancy. The culture determines the meaning of pregnancy among young women is due to social status, health and gender relations.

The increasing trend of prevalence of teenage pregnancy suggests us to take care of adolescent group in such peri-urban and rural areas and implement a community based activities like information, education and proper communication to vulnerable social high risk groups. Family Life Education is only wide spread programme for young adults to improve attitude toward health behavior.

\section{REFERENCES}

Adhikari, R. (2003). Early marriage and childbearing: risks and consequences. (World Health Organization, 2003, Geneva); Retrieved from http://apps.who.int/reproductive-health/ publications/towards_adulthood/7.pdf.

Barker, GK \& Rich, S. (1992). Influences on adolescent sexuality in Nigeria and Kenya. Journal of Studies in Family Planning 23:199210. 
Chedraui, P., Hidalgo, L., Chavez, M., Glenda, S.M. (2004). Determinant factors in Ecuador related to pregnancy among adolescents aged 15 or less. Journal of Perinatal Medicine.; 32: 337-341.

Myors, K., Johnson, M., \& Langdon, R. (2001). Coping styles of pregnant adolescents (2001). Public Health Nursing. Vol. 18, Issue, 1, pp.2432.

Lawlor, S.M. (2004). Teenage pregnancy rates: high compared with where and when? Journal of the Royal Society of Medicine. 2004;97:121-123.

Mathur, S., Mehta, M., \& Malhotra, A. (2004). Youth reproductive health in Nepal: is participation the answer? Engender Health, New York. 2004; Available from: http://catalog.icrw.org/docs/ nepal 0104.pdf.

Mehra, S., \& Agrawal, D. (2004). Adolescent health determinants for pregnancy and child health outcomes among the urban poor. Indian Pediatrics, 41:137-45.

NDHS. (2001). Nepal demographic and health survey. Kathmandu: Family Health Division, Ministry of Health.

NDHS. (2016). Nepal demographic and health survey. Family Health Division, Ministry of Health.

Neupane, I. (2014). Social consequences of teenage pregnancy and its impact on health in peri urban areas of Kathamandu valley. Third Eye, 2(2).

Park, K. (2011). Park's textbook of preventive and social medicine (21 ${ }^{\text {st }}$ Edition). Jabalpur: M/S Banarashibes, Bhanot Publisher.

Population Reference Bureau. (2000). The world's youth. Washington DC.; Retrived from: http:// www.prb.org/pdf/WorldsYouth_Eng.pdf.

Singh, S. \& Darroch, J.E. (2000). Adolescent pregnancy and childbearing: Levels and trends in developed countries. Family Planning Perspectives, 32:14-23.
Shrestha, D. (2012). Reproductive health'; National and international perspectives. Kavre: Narayan Devi Shrestha.

Stone, N., Ingham, R., \& Simkhada, P. (2003). Knowledge of sexual health issues among unmarried young people in Nepal. Asia-Pacific Population Journal, 18: 33-54.

The World Bank. (2004). Children and youth, Washington DC. Available from: http:// siteresources.worldbank.org/INTCY/ Data/20333440/YIN-SA.pdf.

UN. (1997). The right to reproductive and sexual health. United Nations Department of Public Information (DPI/1877) . Retrived from: http://www.un.org/ecosocdev/geninfo/women/ womrepro.html.

United National Development Programme. (2015). Human Development Report. UNDP.

UNFPA. (2013). State of World Population 2013, New York: UNFPA.

UNFPA. (2017). State of World Population 2017. New York: Prographics, Inc.

UNICEF. (2005). Fighting HIV/AIDS strategies for success $2002-2005$.

Viegas, OA., Wiknsosastro, G., Sahagun, GH., Chaturachinda, K., \& Ratnam, S.S. (1992). Safe childbirth needs more than medical services. World Health Forum, 13: 59-65.

WHO. (2005). Facts and figures from the World Health Report. World Health Organization, Geneva. 2005; Retrieved from: http://www. who.int/whr/2005/media_centre/facts_en.pdf

WHO. (1991). Maternal mortality ratios and rates: A tabulation of available information. World Health Organisation (3rd edition), Geneva.

Wight, D., Henderson, M., Raab, G., Abraham, C., Buston, K., Scott, S., \& Hart, G. (2000). Extent of regretted sexual intercourse among young teenagers in Scotland: a cross sectional survey. British Medical Journal. 320: 1243-44. 